\title{
Civilisations
}

Revue internationale d'anthropologie et de sciences

humaines

42-2 | 1993

enQuete d'identité

\section{Social psychological reactions to social change and instability : fear of status loss, social discrimination and foreigner hostility}

\section{Manfred Bornewasser}

\section{CpenEdition}

Journals

Édition électronique

URL : http://journals.openedition.org/civilisations/2310

DOI : 10.4000/civilisations.2310

ISSN : 2032-0442

\section{Éditeur}

Institut de sociologie de l'Université Libre de Bruxelles

\section{Édition imprimée}

Date de publication : 1 décembre 1993

Pagination : 91-103

ISBN : 2-87263-108-9

ISSN : 0009-8140

\section{Référence électronique}

Manfred Bornewasser, «Social psychological reactions to social change and instability : fear of status loss, social discrimination and foreigner hostility », Civilisations [En ligne], 42-2 | 1993, mis en ligne le 30 décembre 1996, consulté le 21 avril 2019. URL : http://journals.openedition.org/civilisations/2310 ; DOI : 10.4000/civilisations.2310

Ce document a été généré automatiquement le 21 avril 2019

(c) Tous droits réservés 


\title{
Social psychological reactions to social change and instability: fear of status loss, social discrimination and foreigner hostility
}

\author{
Manfred Bornewasser
}

\section{Migration and xenophobia}

1 Social instability and social change predominantly are caused by political and socioeconomical crisis. They often are accompanied by migration, leading to a differenciation of natives and foreigners. In the German history there are a considerable number of migration experiences (Bade, 1992). In face of these historical experiences one might suppose that migration today is a normal phenomenon in Germany. Unfortunately, this is not the case. On the contrary, faced with a new movement of migration a lot of Germans show once again obvious signs of anxiety, hostility and even violence.

\section{Anthropological and social components of xenophobia}

In the specific literature it is often assumed that insufficient information and awareness about these historical factus are the main reasons of xenophobia. This assumption is problematic. Ethnological studies show that even former refugees manifest today the same adverse attitudes against foreigners as those natives who have never changed their living place (Lehmann, 1991). Contrary to this assumption, in the present paper it is assumed that xenophobia is a rather uncontrollable affectivereaction of people who in specific social situations are confronted with foreign objects or persons.

3 Xenophobia thus constitutes a kind of emotion. It is to be realized whenever unknown and negatively evaluated persons, events or objects appear or approach and lead to sorne 
kind of defensive mobilisation and even a readiness of an offensive attack. In social systems, xenophobic reactions additionally reflect a fear of loss. This fear concems social status, the inscription of rights and privileges as weIl as the allocation and the access of scarce resources. In this sense xenophobia includes two components, an anthropological and a social one.

\section{Anthropological component : Differentiation of the inside and the outside}

4 The central assumption concerning the anthropological component is the differentiation of the inside and the outside. This differentiation has two aspects: a subjective psychological and a objective geographical one.

The subjective psychological component concerns familiarity. From the beginning of their lives, people tend to establish a familiar world around themselves. They assimilate (and sometimes accomodate to) their extemal environement, become acquainted to it and internalize it. By that way, people exert more and more control over their world : they learn which people in which positions belong to their social environment, they learn the meaning of symbols, what kind of behaviour might be expected and which events are to be predicted. Finaly, the familiar environment is a small world which is taken for granted. It has become a place of safety. In sociology this familiar world is differently described e.g. as Lebenswelt (Schütz, 1982) or as Sinnwelt (Berger \& Luckmann, 1969).

6 Acquiring a familiar world is associated with choice. The familiar world is a selected and restricted world. It is constituated by a selection of possibilities which is valid for a restricted number of people in a restricted area. Selection and restriction - based on choice and mediated by consentual obligations - are the main prerequisites of security, controllability and expectability. People assume that their familiar world endures, that it is reproduced and that it will continue in the future. In this sense, the continuous familiar world is the main source of one's identity.

7 Besides this more subjective subcomponent, the familiar world has also a geographical extension (Demandt, 1991). Old ethnic as well as modem societies are markedly characterized by their spatial extension. Territoriality is a main aspect of modern states (Heckmann, 1988; Reiterer, 1991). Hence, there has always been a struggle about a territorial boundaries. The word "boundary" in its fundamental spatial sense describes the extreme parts of a territory which is determined by its name. A boundary cannot be described without reference to spaces, that are devided, and a space is not to be determined without reference to its environment. Here is the connection to political power: separation and division of geographical spaces in the sense of different ethnic regions or national territories always imply acts of power, and boundaries are the result of a conflict between internal and extemal forces.

This aspect of power is the basis of the negative, more repulsive meaning of the word "boundary". A space is closed by boundaries and entrance is forbidden by agencies of force. This may be an angel as in the case of Adam and Eve's expulsion from the paradise, an automatic firing advice or some kind of controlling servant. Boundaries hinder a free exchange of people, ideas and goods. When the equilibrium between internal and external forces becomes or is expected to become instable, the boundary even become a frontier with military and defensive character. 
However boundaries also have positive meaning. Boundaries protect the members of a social system against the infinite eagerness of the scarce resource of territory and thus are a basis of peace. The Latin word "pax" is associated to the words "pango "(to set) and "pagus "(administrative district), which describe a region which is closed by boundaries, inside of which people are obliged to be peaceful. To guard peace is the duty of the sovereign, whose competence is always limited in space.

This fundamental idea of a limited space is the crucial one concerning xenophobia. With the insiders, there is always the fear of a territorial hunger of the outsiders, of their eagerness and readiness for a violent occupation of one's own territory. Complementary there is a fear of an acute invasion or a silent infiltration, which leads to a weakening of the inner forces thus decreasing the defensive power and increasing the risk of overmanning. This fear is maximized in the picture of a boat as a limited space of safety in a threatening environement. There is not only the menace of flooding, but also that of sinking, when there are too many people in the boat and the load becomes too heavy.

11

Therefore, xenophobia, as an anthropological constant with all its affective concomitants, will appear :

1. when the boundaries of the geographical and political system are trespassed and the territory of a social unit is menaced, i.e. the basis of internal organization, of peace and individual welfare are endangered ;

2. when the boundaries of the familiar world are infringed.

These boundaries are to be seen as a slash between the familiar and the unfamiliar, strange or sinister, which is opposed, attacked or mystified. The traditional familiarity is shaken by realizing that other people are free to perceive things differently and to behave alternatively than oneself.

In this respect foreign events, objects and persons which enter a familiar system defined as a limited space and a political entity, will always have a dangerous potential. That is why foreigners elicit some kind of affective reaction like anxiety leading to opposition, mystification and sometimes even hostility and attack.

\section{The social component : Differentiation inside the social system}

15 The anthropological component describes affective reactions on the basis of some kind of interpersonal competition. The social component, however, concerns more protective mechanisms of social organizations, the aim of which is a reduction of interpersonal hostility. In this respect the social component leads in the first step to the decrease of affective reactions. However, in a second step, when the protective functions are endangered, the social component might contribute to a further increase of xenophobic reactions.

Social systems are seen as restricted entities. These restrictions concern not only boundaries which limit the geographical space of the system, leading to a differentiation of the inside and the outside, but they especially deal with personal freedom and access to resources. These two kinds of restrictions inside the social system constitute two main subcomponents : a normative and an evaluative one. 

exerted norms and traditions. These represent obligations of different kind and a strictness which restrict actions possibilities of each member. At the same time they are the basis of social security and predictability. During socialization the majority identifies with these norms and they become accepted. This acceptance of the system's norms it the main precondition for the achievement of a membership status and the inscription of specific rights and privileges, by which members are to be differentiated from nonmembers. Normally, foreigners from outside the system are exc1uded from these rights and privileges. they are not in the same way restricted in their freedom as the natives, they have again a threatening potential for the whole system and its organization. With their unfamiliar views of the world, their unusual behaviour and coping strategies they might shake traditional and valid standards of living. Consequently, the world that has been taken for granted till that moment, might lose its obviousness and self-evidence.

The evaluative subcomponentconcerns the access to social resources. Members of social systems take positions that offer a different access to resources which are to be seen as the basis of their individual welfare. This leads to a differentiation of top and bottom, of superior and inferior groups or strata with a high or a low status. Similarly to the way the whole system stands against its environment, the socially evaluated groups inside the system are also differentiated from each other by a similar mechanism of social closure (Weber, 1976). This mechanism can be described as a strategy of social groups to main tain or even to increase their rights and privileges by the subordination of other groups. By this closing mechanism, differential access to resources is granted to members, whereas non-members are excluded from rights and privileges. Psychologically, this clos ure mechanism guarantees a positive selfesteem or a positive social identity.

On the basis of this clos ure mechanism there results a hierarchy of differently evaluated social groups. Once again, each of these social groups represents a familiar world of normative obligations and economic participation. As soon as this hierarchy seems to be jeopardized - for example by large amounts of foreigners who penetrate into a social system, try to stay permanently and start to compete for scarce resources - a xenophobia results that is often accompanied by hostility and violence.

Briefly, xenophobia has anthropological and social roots.

Also, it seems plausible to assume, that it is a universal phenomen that occurs with all people in all societies whenever there appears a menace of territorial claims and/or a disruption of one's familiar world by strange events or foreigners. This disruption arrouses affective reactions which are often accompanied by fears of uncontrollability, unexpectability, fears of loss of status and an increase of hostility.

The same is true in the case of ethnocentrism as some kind of acceptance of one's familiar world, which simultaneously is evaluated as a rather correctly organized world. In this sense both ethnocentrism and prejudice mean a positive identification of the members with one's own social organization ant its normative rules and a mainly affective rejection of alternative possibilities. Thus, ethnocentric reactions and prejudices are to be conceptualized primarly as commands on social systems with their specific holistic features. It is Weber who states that this affective repulse is a quasi natural social 
reaction. However this does not imply that each member has identical opinions nor that the outgroup is seen as a more homogeneous collective than the ingroup.

\section{Ambivalence of the unfamiliar}

It was argued that strange objects and foreign people possess a dangerous potential for natives and their familiar environment. However, there is a positively evaluated potential too. As we all know, strange and unfamiliar events and persons do not always arouse anxiety and hostility. People are curious and open to new impressions, they like to go abroad for holidays. Young people glorify American rock and pop singers, Germans speak foreign languages and participate in a lot of exchange programs. Our everyday language is full of anglicisms and we are always looking for new and exotic fruit and meals. Italian pizzerias and Greek restaurants are frequent in our cities. Additionally, a lot of foreigners are working in music, arts, science, and commerce without running any risk of hostility.

It is therefore necessary to have some more differentiations in order to decide under which conditions foreigners either arouse some kind of xenophobia, or are accepted or even admired. As most of experiences in history show, there is less xenophobia :

- when foreigners have a high social statuslike the judges in Italian towns during the $16^{\text {th }}$ century, the English specialists in coal mining at the beginnings of the $18^{\text {th }}$ century in the Ruhr valley or Japanese bankers and conductors nowadays ;

- when foreigners intent to stay only for short periodsand then either go back or migrate to other places like the Polish people who in the early decades of the $19^{\text {th }}$ century either went back to Poland or migrated to France, or like Russian itenerant workmen or the Jewish peddlers in the beginnings of the $19^{\text {th }}$ century (Schmidt, 1987);

- when natives have a chance to control the coming of foreigners, when they are intentionally hired for work like our guestworkers during the sixties or have some other kinds of permission to stay like allied soldiers or accepted asylum seekers.

When foreigners fulfill these criteria, there are no severe problems of xenophobia. This was exactly the role the guest workers in the sixties were expected to take. These ideas were implicated in the rotation principle too. According to this principle, guest workers like the itenerant workmen in earlier times - should only stay for a couple of years in Germany, then they should go back to their native country and be replaced by other workers.

However, in practice, this idea did not work perfectly for different reasons. What happend in reality was, that the guestworkers together with their families settled and tried to stay permanently. Consequently, the foreigners became more and more social competitors. In this situation there is a risk that the relation of natives and foreigners changes rapidly (Simmel, 1992). Now the foreigner is no longer admired for being free of normative obligations, but his freedom is seen as a danger for the continuity of the natives' familiar world. His being different is accentuated and the commonalities are neglected, the fortuitousness of social contacts stressed and negatively evaluated against the traditional bindings of kinship network and neighbourhood. As a consequence, the foreigner is now seen in an adverse perspective and he is expected to assimilate with the main traditions and values of the native society.

These expectations find their expression in attitudes concerning foreigners. Reuband (1989) and Wiegand (1992) document the slope of negative attitudes against guestworkers 
during the last decade. As documented by these data, the percentage of negative attitudes has decreased during this period. However, the readiness to integrate foreigners is still low. In 1988, 57 \% of a representative sample call for more assimilation of foreigners, $36 \%$ vote for a return to their native countries when unemployment increases, $38 \%$ argue for a prohibition of any political activity and $33 \%$ for endogamy. Nearly $50 \%$ of all Germans have reserves against a marriage of their children to foreign children. Comparable results were brought about with Dutch and Swiss samples (Emnid, 1989). In the Netherlands $78 \%$ of a sample of 1.016 men and women had the opinion that foreigners who are living for a longer period in the Netherlands should assimilate to the traditions of the host society.

This demand for assimilation corresponds to a permanent low rate of social con tracts. Although there is a slight increase in arbitrary contacts during the eighties, especially in friendship relations and in neighbourhood, in total, $63 \%$ of all Germans still do not have any contact with guestworkers (Emnid, 1991).

In Germany these negative attitudes correspond to a lot of indicators showing that integration with the German society takes place only very slowly (ISI-Report, 1990, 3). Only a neglectable percentage of all foreigners wants to become German; it is more often the case that foreigner pupils go to basic schools and to special schools for handicapped children than German pupils ; foreigners work predominantly in industry, especially in physically strenous jobs, and the rate of unemployment is still higher for foreigners, especially for Turks than for Germans. On the other hand, remigration seems to become more and more difficult, as both guestworkers of the first and second generation do no longer feel accepted in their old societies.

These data show that the amount of competition, between Germans and foreigners is much less than right-wing propaganda wants to make us believe. So it might be assumed that the missing readiness to assimilate to the native traditions is often a more important indicator for negative attitudes against foreigners than unemployment of natives (Schönwälder, 1991). However, it should be noted that a low readiness to assimilate and belongingness to low status groups on the part of the foreigners are normally confounded. To be a member of a low status group also implies aspects of discrimination, especially when this belongingness is combined with living in ghettos and some kind of solidarity inside these minority groups.

As a conclusion it might be supposed that attitudes against guestworkers are still negative, although they have become more positive during the last decade. This amelioration has taken place, despite the fact that the economical situation has become worse in Germany and the readiness to assimilate is still rather low. The reason for this surprising development is probably to be seen in the fact that the presence of guestworkers is still desired and regarded as an advantage. In 1990 only $18 \%$ of a sample of Germans stress disadvantages (young people till 24 years $13 \%$; people over 65 years $34 \%)$. In this context is should be mentioned that the resettling of Germans from the former GDR and especially from easten European countries is assessed much more negatively (disadvantageous : $42 \%$ resp. $53 \%$, ISI-Report, 1991. 5). The same is true for asylum seekers. 


\section{Xenophobia in low status groups}

As the data show, guestworkers have a lot of features which reduce xenophobia. There are some problems with the Turks, who are culturally more distant than for example Italians or Greeks. However, even the members of this ethnic group are not seen as real competitors, because most of them earn their own money. There are much more problems nowadays with asylum seekers, especially on the side of natives, who belong to less evaluated status groups, who have little income, little education and who live in bad and unstable conditions (Müller, 1991). It is exactly this group which feels threatened and is anxious of a further loss of status. Additionally, this group often has the impression that the political leaders are either not really interested in their problems or neglect them. These estimations and feelings are of central importance in their xenophobic reactions, which document a high readiness to exert violence.

Unfortunatley, conclusive empirical data that demonstrate the crucial relation of low status and hostility are so far missing. However, a lot of indirect evidence is available. Social psychological studies concerning prejudice show a remarkable correspondence between blatant forms of prejudice and educationallevel ( $\mathrm{r}=-0.21$. cf. Wagner \& Zick, 1992).

34 Law educated people develop more interethnic conflicts and have more negative opinions concerning the advantages of the presence of foreigner groups (ISI - Report, 1991, 5). Investigations concerning right-wing extremisme reliably document a low education of violent actors as well as an overproportionate belongingness to low status groups (Backes \& Jesse, 1989). A study of Kalinowsky et al. (1986) on indictment documents shows that a great amount of actors are rather young and badly educated. Similar results have been reported by Jokusch (1992) concerning the personality structure of those young actors, who have been sentenced during the so called Tschernobyl-trial in Zittau/Saxonia.

These results should not be taken as a hint showing an association between the level of education and xenophobia. Law education normally is correlated with other socioeconomic indicators too, which together contribute to the experience of inferiority and deprivation. Here it is assumed that it is deprivation and not education that is the central cause of hostility.

\section{What is to be done?}

Xenophobia as it has been defined here cannot be totally avoided. It is an anthropological constant of any kind of competition and a concomitant of social structure which divides social entities and at the same time leads to a differentiation inside a social system. Although this structuring is an effective, perhaps the most effective, means to reduce xenophobia, there are situations where the protective functions of social organization seem to be threatened by the presence of foreigners. These social threats, which often are combined with a lot of anger evoking cognitions, contribute to increase of xenophobia and to a release of aggressive behaviour.

What follows from this conceptualization is that usual psychological measures like communication, persuation and attitude change via information are less effective 
measures to remove xenophobia. Information has only little impact on emotional processes. Thus, information giving can only be an escorting mean.

Acute events of xenophobic attacks ask for effective measures of suppression to be practiced by our legal system. These measures imply a consequent prosecution of actors, the avoidance of any kind of comprehension or even sympathy from the part of legal and political institutions and the strict applicaton of our laws. The actors must know that they are punished and do not find any kind of social support from within our legal institutions. In the long run only effective political measures could be helpful to reduce xenophobia. When xenophobia is seen as an affective reaction caused by a disruption of a familiar world with its geographical, normative and evaluative aspects, the general direction of an coordinated interventions is clear : it is the maintenance of social stability in our society and thus the avoidance of any kind of social fear. The concrete interventions might be classified along the component model of xenophobia in three categories :

40 1. The first category concerns the legal conditions of entrance as well as the conditions of staying and remigration. In this respect the dynamic dialectical interplay of distance and proximity, of being far away or near by or of being a member or a non-member with all its implications for equality and justice, has to be submitted to unequivocal laws. In the case of immigrants from eastem European countries, refugees and asylum seekers presently these are the most critical groups - these conditions are not all clear. There is a need for more differentiation between foreigners with different legal status. There is a need to differentiate the permissions of long - and short stayings for different groups of foreigners. There is a need for an effective policy to handle especially refugees and asylum seekers. This handling concerns formal affairs of entrance, admittance and reboundment as well as the conditions of staying during the phase of admittance and early integration in different social networks. And finally there is a need to avoid that somebody has to become an asylum seeker in order to obtain temporarly or permanent residence in Germany. In part it is our own law that enforces foreigners to abuse it and thus to becomne sham asylum seekers. This reproach that is often used in political discussions (Thranhardt \& Wolken, 1988) implies suppositions of illegitimacy, injustice and inequality, which then are the cognitive basis of aggressive behaviour of young Germans.

41 2. The second category concerns the integrative conditions of living as a foreigner in a host society. These conditions have to be created in such a way that they might become effective means of some kind of integration. This need not to be assimilation, but it seems necessary to have at least some fundamental common rules which are acceptable to all members of the society, independent of social status of the subgroups as majority or minority. This may result in sorne kind of cultural mix, pluralistic identity or a multiple loyalty on the basis of sorne fundamental commonalities. This strategy of creating a basic set of obligations might be supplemented by language programs for foreigners concerning their native language, by avoiding ghettos and prefering a good mixture of Germans and foreigners, by offering educational programs especially for the foreigners of the second and third generation and by a lot of political and cultural activities like foreigner boards or cultural associations of Germans and foreigners. In this context, social workers together with social psychologists could find interesting perspectives on how to create a willingness to come together and to manage contacts. concern both foreigners and native belonging to low status groups. They imply better 
education, higher incomes, more secure jobs, better flats and a better infrastructure in living areas. These improvements might lead to an increase of life quality and a better self-esteem for both Germans and foreigners. In the long run, this is an important precondition of overall stability and security. It seems as if xenophobia is reduced or leads to less hostility when the socioeconomic de privation is low.

\section{BIBLIOGRAPHIE}

Backes, U. \& Jesse, E., 1989, Politischer Extremismus in der Bundesrepublik Deutchland, Köln, Verlag Wissenschaft und Politik

Bade, K. J. (ed.). 1992, Deutche im Ausland - Fremde in Deutchland. Migration in Geschichte und Gegenwart,München, C.H.Beck.

Berger, P. L. \& Luckmann, T., 1969, Die gesellschajtliche Konstruktion der Wirklichkeit, Frankfurt, Suhrkamp.

Demandt, A. (ed.). 1991, Deutschlands Grenzen in der Geschichte, München, C. H. Beek.

EMNID, 1989 : Niederlande : Türken am stärksten von der Rassendiskriminierung betrolfen .

EMNID, 1989 : Integrationsbereitschajt gegenüber Auslândern weiterhin gering.

Heckmann, F., 1988, "Volk, Nation, ethnische Gruppe und ethnische Minderheiten. Zu einigen Grundkategorien von Ethnizität”,Osterreichische Zeitschriftjür Soziologie, 13, pp. 16-31.

ISI-Report 1990, 3, Ausländer in Deutchland : Ein langwieriger Integrationsprozess, pp. 5-9.

ISI-Report 1991, 5, Aussiedler aus Osteuropa weniger gern gesehen, pp. 10-14.

Jokdsch, D., 1992, "Gewalttaten von Skinheads und "Neonazis" - Psychologische und psychiatrische Aspekte", Vortrag auf der Deutsch-israelischen Tagung von Juristen Psychiatern, 29.04. -7.05 .

Kalinowsky, H. H., 1986, Rechtsextremismus und Strajrechtspjlege. Eine Analyse von Strajrechtsveifaren wegen mutmasslicher rechtsextremisticher Aktivitiiten und Erscheinungen, Köln.

Lehmann, A., 1991, Im Fremden ungewollt zuhaus, München, C. H. Beek.

Moller, K., 1991, “Gewalt und politischer Extremismus Herausforderungen für die Jugendarbeit”, in : Neue Praxis, 21. pp. 281-299.

Reiterer, A. F., 1991. “Theorie der Ethnizitât - eine allgemeine Entwicklungstheorie ?”, in : Osterreichische Zeitschrift jür Politikwissenschaft, 20, pp. 59-72.

Redband, K.-H., 1989, “Wächst in der Bundesrepublik die Ausländerfeindlichkeit ?”, in : Neue Praxis, 19, pp. 270-274.

Schmidt, M., 1987, "Handel und Wandel. Über jüridiche Hausiere und die Verbreitung der Taschenuhr im frühen 19. Jahrhundert." in : Zeitschrift für Volkskunde, 83, pp. 229-250.

Schonwälder. K., 1991. "Zuviele Auslânder in Deutschland ? Zur Entwicklung auslânderfeindlicher Einstellungen in der Bundesrepublik", in : Vorgänge, 4, pp. 1-11. 
Schütz, A., 1982, Das Problem der Relevanz, Frankfurt. Suhrkamp.

Simmel, G., 1922, Excurs über den Fremden, in : Simmel Soziologie, Tübingen, Mohr.

Thränhardt, D. \& Wolken, S., 1988, Flucht und Asyl. Injormationen, Analysen, Eifahrungen aus der Schweiz und der Bundesrepublik Deutschland, Freiburg, Lambertus.

Wagner, D. \& Zick. A., 1992, Formai education and ethnie prejudice. Vortrag auf dem Intergruppen-Meeting, Amsterdam.

Weber, M., Wirtschaft und Gesellschaft, Tübingen, Mohr.

Wiegand, E., 1992, Zunahme der Ausländerfeindlichkeit ? Einstellungen zu Frernden in Deutschland und Europa, in : ZUMA-Nachrichten, 31, pp. 7-28.

\section{RÉSUMÉS}

Il est souvent admis que l'information et la conscience des faits historiques et culturels sont les principales cause de l'hostilité envers les étrangers et de la xénophobie. Contrairement à cette assertion, l'article affirme que ces deux derniers comportements sont des réactions affectives aux personnes étrangères, qui proviennent d'attitudes fortement émotionnelles. Une première attitude anthropologique se rapporte à la différenciation d'un monde intérieur familier et d'un monde extérieur inconnu. La familiarité est considérée comme la principale condition préalable à la sécurité. Un deuxième fait social concerne la différenciation des personnes à l'intérieur d'un système social. Cela est lié à une subdivision entre le haut et le bas de l'échelle sociale et l'accès différentiel aux ressources sociales. La xénophobie et l'hostilité envers les étrangers ne sont pas des réactions courantes de n'importe quel habitant d'un système social vis-à-vis d'étrangers de tous horizons. Ainsi, ü est prouvé que les étranges ont un potentiel d'attraction et de menace ambivalent, et qu'une majorité des autochtones du bas de l'échelle sociale se sentent menacés et se montrent hostiles.

\section{INDEX}

Mots-clés : changement social, instabilité, statut social, xénophobie

Keywords : social change, instability, social status, xenophobia

\section{AUTEUR}

\section{MANFRED BORNEWASSER}

Université de Münster, Allemagne 